This is an author produced version of a paper published in Plant Ecology. This paper has been peer-reviewed and is proof-corrected, but does not include the journal pagination.

Citation for the published paper:

Maria Johansson, Tuulikki Rooke, Masresha Fetene \& Anders Granström. (2009) Browser selectivity alters post-fire competition between Erica arborea and E. trimera in the sub-alpine heathlands of Ethiopia. Plant Ecology. Volume: 207 Number: 1, pp 149-160. http://dx.doi.org/10.1007/s11258-009-9661-9

Access to the published version may require journal subscription. Published with permission from: Springer

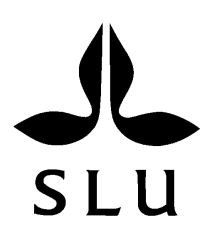

Epsilon Open Archive http://epsilon.slu.se 


\title{
Browser selectivity alters post-fire competition between Erica arborea and $E$. trimera in the sub-alpine heathlands of Ethiopia
}

Published in: Plant Ecology, Volume 207, Number 1, 149-160, DOI: 10.1007/s11258-009-9661-9

Authors: Maria Johansson ${ }^{1}$ Tuulikki Rooke ${ }^{2}$ Masresha Fetene $^{3}$ and Anders Granström ${ }^{1}$

1: Department of Forest Ecology and Management, Swedish University of Agricultural Sciences, SE-901 83 Umeå, Sweden

2: Department of Wildlife, Fish and Environmental Studies, Swedish University of Agricultural Sciences, SE90183 Umeå, Sweden

3: Department of Biology, Faculty of Science, Addis Ababa University, P.O. Box 30193, Addis Ababa, Ethiopia

Corresponding author: email: Maria.Johansson@ svek.slu.se, tel: 0046-90-786 8396 fax: 0046-90-786 6163

Keywords: Erica arborea; Erica trimera; Afro-alpine heathland; fire management; browser selectivity; tannin

\begin{abstract}
Mammalian herbivores have the potential to alter the competitive relations of woody species, if consumption is unevenly distributed between species. At elevations above $3500 \mathrm{~m}$ in the southern Ethiopian highlands, vegetation is dominated by Erica arborea and Erica trimera. Both species can potentially grow into short trees, but are burnt on a rotation of 6 to 10 years, and regenerate by re-sprouting from belowground lignotubers. The regenerating scrub is heavily browsed by cattle. We set up browsing exclosures at three burnt sites to quantify the impact of browsing over a three-year period. When protected from browsing, E. trimera had similar or better height growth than Erica arborea, but in browsed vegetation, Erica arborea instead grew taller. Browsing was more intense on E. trimera in the first years after fire, indicating a difference in palatability between the species. We checked if browse quality differed, by analysing shoot contents of acid detergent fibre, protein, phenolics and tannins. Contrary to expectations the preferred E. trimera contained more acid detergent fibre, less protein and had a higher tannin activity than E. arborea. Although the vegetative growth of $E$. arborea is favoured relative to E. trimera under high browsing pressure, rapid change in abundance would not be expected, since short-interval fire will repeatedly eradicate any gains in vegetative growth. However, within the typical fire return interval of less than 10 years, E. trimera barely reach a reproductive state, whereas E. arborea flower profusely. Under the current regime of fire and browsing this may in the long run be more important than differences in height growth, leading to a gradual increase in the proportion of E. arborea.
\end{abstract}




\section{Introduction}

Browsers are powerful selective agents with the potential to shape ecosystem structure and function by altering the interspecific competition between woody plants (Augustine and McNaughton 1998; Hobbs 1996). The net effect of browsing on plant competition depends on plant growth rate, tolerance to herbivory, and herbivore selectivity (Dwire et al. 2006; Horsley et al. 2003; Mills 1986; Skarpe and Hester 2008). The latter is often regulated by the type and amount of secondary defence compounds within the plants (Harbourne 1991). However, effective defence comes with a cost. Heavily defended plant species are typically more slow-growing, which becomes a disadvantage when the intensity of herbivory is relaxed (Herms and Mattson 1992; Koricheva 2002). There are also more indirect effects of plant defences, for example impairment of litter decomposition (Grime et al. 1996; Wardle et al. 2002), and increased flammability (Ormeno et al. 2009; Owens et al. 1998; Snyder 1984).

At elevations above c $3200 \mathrm{~m}$ asl in the East African Mountains, Erica (tree heather) species dominate the vegetation and form a relatively well defined zone, termed the Ericaceous Belt by Hedberg (1951). At the lower part of this belt the Erica grow into short trees, but at higher altitudes the same species are kept in a shrubby state due to recurrent fires (Fetene 2008; Hedberg 1971), resulting in a relatively well defined tree line. In Bale Mountains, in the Southern Highlands of Ethiopia, people intentionally burn the ericaceous vegetation above $3500 \mathrm{~m}$ elevation (Wesche et al. 2000), in order to produce better pasture for their cattle. The burnt shrubs regenerate by shoots from underground lignotubers, and seedling regeneration is rarely observed (Teshome 1999; Wesche et al. 2008). The dominant mammalian herbivores are domestic, free-roaming cattle (Bos taurus indicus), and to a lesser degree the native Mountain Nyala (Tragelaphus buxtoni).

The Erica scrub is a mosaic of patches of different age since fire, with Erica bushes reaching a height of approximately 1.5 to 3 metres before burning. At this stage, the Erica-dominated fuel bed is highly flammable, due to the small leaf size and fine branching pattern (Pereira et al. 1995). Fire return interval is normally between 6 and 10 years, and the sizes of the burnt patches typically range between 0.5 and 5.0 ha (M. Johansson, unpublished data). The regenerating individual Erica bushes are relatively evenly spaced (ca. 0.5$2.5 \mathrm{~m}$ ), and separated by a sward of grasses, sedges and herbs such as Trifolium spp. and Haplocarpha spp. that regenerate from the seed bank and underground structures. For the first years after fire, there is about equal cover of Erica and the grass/herb sward. As the bushes grow taller and wider the canopy closes at an age around 5-7 years, shading out the grass/herb sward. This results in a continuous Erica heath with the ground covered by mosses and Erica litter (M. Johansson, unpublished data). In the Bale Mountains, the Erica scrub consists of two different species; Erica arborea (L.) and E. trimera (Engl.) Beentje, which are difficult to distinguish from each other. Therefore they have often been wrongly identified, since they grow completely intermixed with each other, and have only slightly different habitus (Hedberg 1971; Miehe and Miehe 1994). The relative proportion of the two species varies but E. trimera is usually the most common (Miehe and Miehe 1994).

Plants in the Ericaceous family are generally rich in phenolic compounds (Harborne and Williams 1973), and Erica arborea is well-known from the Mediterranean region to have high concentrations of tannins (del Pino et al. 2005; Frutos et al. 2002; Gasmi-Boubaker et al. 2006; Selje et al. 2007), and to be unpalatable to livestock (Bartolome et al. 1998; González Hernandez 2004) and wild browsers (Focardi and Tinelli 2005; Gonzalez Hernandez and Silva-Pando 1996). Despite the reputed unpalatability of Erica species, the Erica scrub in Bale Mountains is heavily browsed by cattle. In these frequently burned heathlands we observed that $E$. arborea seems to outgrow $E$. trimera in the first years after fire (Fig. 1), and hypothesized that this was an effect of differential browsing pressure on the two species.

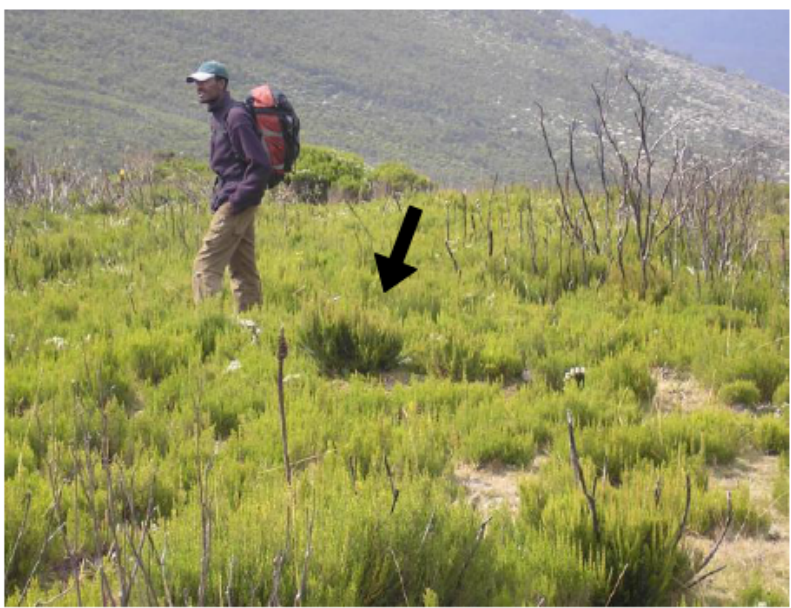

Fig. 1 Browsed Erica heath two years after fire. The arrow points to one taller individual $E$. arborea surrounded by shorter E. trimera

To test if browser selectivity affects the relative performance of these closely related Erica species, we set up a browsing exclosure experiment which we followed over three years after fire. We also sampled a sequence of burns that differed in time since fire, for data on the relative performance of the two species in browsed vegetation. To check for differences in browse quality between the species we sampled shoots of the two Erica species in burns differing in time since fire and analyzed 
them for tannin activity, phenolic content, acid detergent fibre (ADF) and protein content. In this study we ask the following main questions: (1) Are differences in height increment between these two closely related species caused by inherent differences in growth rate or in browsing tolerance, or is it an effect of differential browsing pressure on the two species? (2) Are there differences in browse quality that may account for animal selection?

\section{Materials and Methods}

Study area

The study was conducted in the ericaceous zone of the Bale Mountains, in the Southern Highlands of Ethiopia (Fig. 2).

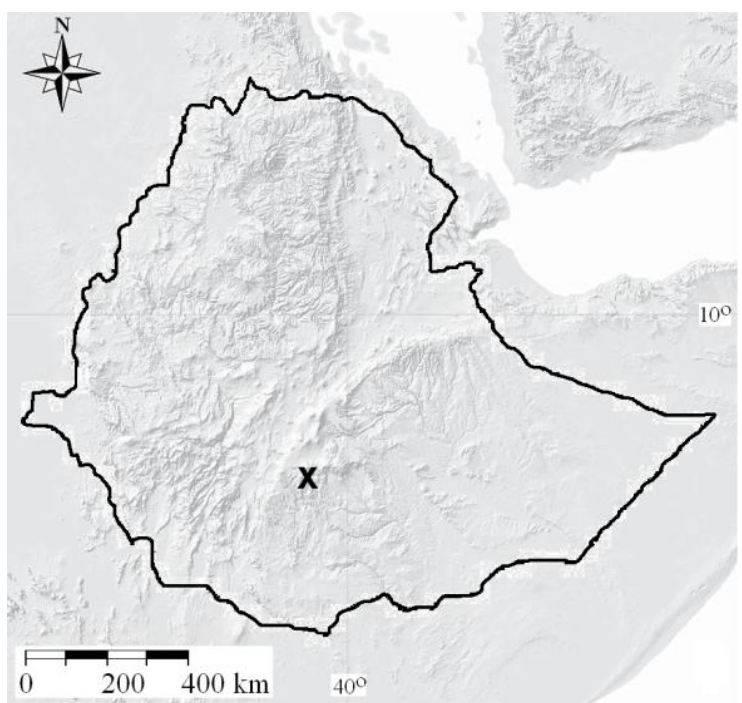

Fig 2. Elevation map of Ethiopia. The study area in Bale Mountains is marked with $\mathrm{x}$.

The bedrock originates from Tertiary lava deposits, and consists of trachytes with basalts and rhyolites which weather to red brown or brown black silty loams (Weinert and Mazurek 1984). The soils of the ericaceous zone are Humic to Leptic Umbrisols (FAO 1998) and typically have a highly organic top soil with a $\mathrm{pH}$ around 5.5 (Yimer et al. 2006). Mean annual precipitation measured over three years in the study area was ca. $1800 \mathrm{~mm}$ (M. Johansson, unpublished data). There is a dry period which is highly variable in length, but typically most pronounced in December-January. Mean daily max and min temperatures were ca. $15^{\circ} \mathrm{C}$ and $5{ }^{\circ} \mathrm{C}$, measured at $50 \mathrm{~cm}$ above the soil surface at two sites at $3500 \mathrm{~m}$ altitude (TinyTag plus 2, Gemini data loggers). The dry season is characterised by more extreme daily temperature fluctuation and common night frosts (Wesche et al. 2008).

\section{Field experiment and sampling}

In March 2005 one browsing exclosure was erected in a newly burnt area in Duro. In order to replicate the study at sites with very similar vegetation, soil and climate, but browsed by different herds of cattle, two additional exclosures were erected in February 2006 at two recently burnt sites in Angafu and Gama (Table 1). The exclosures were in all cases set up less than a month after fire, before the emergence of resprouting shoots. The exclosure fences were $10 \mathrm{x}$ $10 \mathrm{~m}, 180 \mathrm{~cm}$ high, and had 6 strands of barbed wire; the lower $70 \mathrm{~cm}$ was supplemented with interwoven vertical bamboo splints, $10 \mathrm{~cm}$ apart. Next to each fence (in the same burn patch) a nonfenced plot of $10 \times 10 \mathrm{~m}$ was established.

At each site one additional $10 \times 10 \mathrm{~m}$ plot was established in "old" Erica vegetation that had reached a height of ca. $1.5 \mathrm{~m}$. At Duro one plot was also established in a "medium"-aged Erica stand with a height around $0.5 \mathrm{~m}$, to obtain three different age-classes. Four permanent $10 \mathrm{~m}$ line transects were established in each plot $2.5 \mathrm{~m}$ apart. To determine the time since fire at the different plots, basal stem sections of both species were sampled and brought to the laboratory to determine their age. Cross sections were cut with a scalpel, treated with zinc paste, and rings were counted under a magnifier. At these localities, annual rings are regularly produced in the Erica, due to the arrested growth during the dry period (M. Johansson, unpublished data.)

Table 1 Study site characteristics

\begin{tabular}{|c|c|c|c|}
\hline & Duro & Angafu & Gama \\
\hline Altitude ( $\mathrm{m}$ asl) & 3510 & 3530 & 3630 \\
\hline Coordinates (Lat) & $\mathrm{N} 06^{\circ} 51^{\prime} 21^{\prime \prime}$ & $\mathrm{N} 06^{\circ} 50^{\prime} 20^{\prime \prime}$ & $\mathrm{N} 06^{\circ} 50^{\prime} 12^{\prime \prime}$ \\
\hline (Long) & E $039^{\circ} 28^{\prime} 52^{\prime \prime}$ & $\mathrm{E} 039^{\circ} 14^{\prime} 41^{\prime \prime}$ & E $039^{\circ} 14^{\prime} 18^{\prime \prime}$ \\
\hline Fence plot burned in (month, year) & February 2005 & January 2006 & January 2006 \\
\hline Exclosure erected (year) & 2005 & 2006 & 2006 \\
\hline Pre-burn veg. height $(\mathrm{cm})$ & 170 & 150 & 140 \\
\hline Slope (degrees) & 15 & 20 & 7 \\
\hline Slope aspect & $\mathrm{N}$ & SV & $\mathrm{N}$ \\
\hline Age of burns sampled for chemical analyses & 1 (Juvenile) & 1 (Juvenile) & 1 (Juvenile) \\
\hline \multirow[t]{2}{*}{ (years) } & 2 (Young) & 2 (Young) & 3 (Young) \\
\hline & 12 (Old) & 7 (Old) & 7 (Old) \\
\hline
\end{tabular}


All major stems originate from the first shoots emerging after fire.

For the line transects all individual Erica bushes touching the line were marked permanently using paint on the base of the two tallest shoots. Their maximum and average heights were measured yearly in the dry season for 3 (Duro) or 2 (Angafu and Gama) years. There were 6-15 individuals of each species in each transect, giving 25-41 individuals of each species per plot. For the 2007 measurement, the proportion of the surface area of each individual bush that had been recently browsed (i.e. had visible browsed shoot tips) was estimated. For each individual, presence of flowering shoots was also recorded to check the reproductive potential of the two species under the current grazing and fire regime. Erica arborea starts flowering a little bit earlier in the dry season, but for both species the capsules remain visible on the shoots for several months after flowering. In order to quantify the resprouting ability after browsing in the two species, we clipped the top 10 $\mathrm{cm}$ of 5 individuals inside the fences (to simulate the bite from a cow), in February 2007. One year later the length of the resulting axillary shoots were measured. To compare the maximum heights of the two species we located the largest tree-formed individuals of Erica arborea and E. trimera (at Angafu, slightly below the tree line) and measured their height, using a hypsometer. To compare seedling growth of the two Erica species, seeds were collected from both species and sown in peat $(\mathrm{pH} 4.2-5)$ and grown in glasshouse at $20{ }^{\circ} \mathrm{C}$ (day) and $10{ }^{\circ} \mathrm{C}$ (night) with minimum $8 \mathrm{hrs}$ daylight. The height of 25 seedlings per species was measured after 15 months.

To assess forage quality of the two different species, and of different age-classes, we sampled shoots from both Erica species at all three sites, from burns differing in time since fire. Since burns with identical age were not represented at all sites, the burns were grouped into three different ageclasses: "juvenile" (1year), "young" (2-3 years) and "old" (7-12 years) (Table 1). Time since fire was determined by counting rings on basal stem sections (see above).

Since there is a marked dry period affecting growth, the sampling was done both in November 2006 (end of the growing season) and in February 2007 (end of the dry season), to test for possible seasonal variation in chemistry. At both occasions the same burns were sampled but not the same individuals. For each treatment combination (site, age-class and species) samples were collected from 5 randomly chosen individuals. The top $10 \mathrm{~cm}$ of unbrowsed shoots (stem and leaves) was harvested, corresponding to a stem diameter of approximately $1 \mathrm{~mm}$, which is the average diameter down to which the cattle browse the plants. Five shoots from each individual were collected in a paper bag and dried at room temperature. In order to determine dry matter content, three additional samples per treatment were collected in plastic bags and immediately weighed to the nearest $0.1 \mathrm{~g}$ and reweighed after drying in the lab.

Further, in order to be able to analyse whether shoot chemistry was affected by browsing, 5 additional samples per species and site were collected from inside the exclosures in February 2007. For all sampled individuals, maximum and average height was recorded.

\section{Laboratory assays}

The shoot samples taken for assessing forage quality were oven-dried for $24 \mathrm{~h}$ at $40{ }^{\circ} \mathrm{C}$ and ground in a ball mill at $20 \mathrm{~Hz}$ for $2 \mathrm{~min}$, after which a $0.2 \mathrm{~g}$ subsample was extracted in $2 \mathrm{ml} 50 \%$ v/v methanol. Total phenolics were assayed by the Folin-Ciocalteu method according to Waterman and Mole (1994), with tannic acid as standard. The blank consisted of deionised water. The absorbance of all solutions was measured at 760 and $550 \mathrm{~nm}$. The values are expressed as $\mathrm{g}$ tannic acid equivalents per $\mathrm{kg}$ dry mass of leaf sample.

Potential biological tannin activity was quantified by protein precipitation according to the Hagerman radial diffusion method (Hagerman 1987). We added bovine serum albumin (BSA, Fraction V powder, essentially fatty acid free, Sigma A6003-5G) to agarose solution (Type I, Sigma A6013-25G) and made gels in $145 \mathrm{~mm}$ diameter Petri dishes, in which 28 wells, each with a diameter of $6 \mathrm{~mm}$, were punched $2 \mathrm{~cm}$ apart. As standard, a dilution series of Quebracho tannin in $50 \% \mathrm{v} / \mathrm{v}$ methanol was added to eight wells dispersed across the gel. Sample extracts $(20 \mu 1$ in $50 \%$ methanol) were added to 20 wells per gel in a randomised order. The gels were incubated at $30{ }^{\circ} \mathrm{C}$ for at least $96 \mathrm{~h}$. Each extract was analysed on three different gels. Two perpendicular diameters of the protein-precipitated circle were measured under low-magnification microscope, and the mean was used to calculate circle area, from which the well area was subtracted. The net precipitated area was used to quantify tannin activity from the standard curves obtained from the Quebracho tannin standards. The values are expressed as g Quebracho equivalents (QE) per kg dry mass of leaf sample. The nitrogen concentration was analysed by LECO FP-528 Combustion analyzer (anonymous 2000) using EDTA standards. The results were multiplied by the 6.25 conversion factor (Jones 1941) to obtain crude protein content. Acid Detergent Fibre (ADF) was analysed using the ANKOM A200 Filter Bag Technique (anonymous 2005) Samples were individually weighed into filter bags and digested for 75 minutes as a group of 24 in $2 \mathrm{~L}$ of ADF solution.

\section{Statistical analyses}

For all analyses the unit of replication is the individual plant. Kolmogorov-Smirnov tests showed that the data was normally distributed. Differences between species in maximum heights, 
proportion browsed, and resprouting shoot lengths were tested by GLM ANOVAs with species and age-class as fixed factors, and site as random factor. Height differences between fenced and browsed individuals were tested by GLM ANOVA with treatment and species as fixed factors and site as random factor. Seedling height difference was tested with a t-test. Species chemical differences in tannin activity and concentrations of phenolics, ADF and protein, were tested by a GLM ANOVA with species, sampling date, and age-class as fixed factors, and site as random factor. Chemical differences between fenced and browsed individuals were tested by a GLM ANOVA with treatment and species as fixed factors and site as random factor. All statistical analyses were performed using Minitab 15.

\section{Results}

\section{Field measurements}

In browsed vegetation $E$. arborea was significantly taller than E. trimera, for all age-classes above one year $(\mathrm{F}=21.41$; $\mathrm{df}=1,527 ; \mathrm{P}=0.002)$. At Duro, the site where a sequence of three different-aged burns was followed during three years, there was a steady height increase in both species (Fig. 3), but with E. trimera lagging behind.

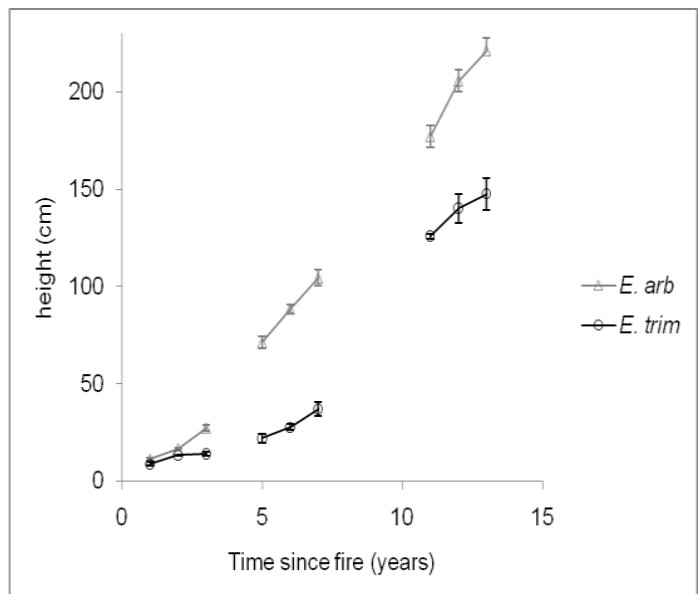

Fig. 3 Average heights of Erica arborea (grey line) and E. trimera (black line) in three different plots of browsed vegetation followed during three years at Duro. Error bars = S.E. $(n=21-41)$

At the age of 13 years, E. arborea was around $2.2 \mathrm{~m}$ tall and E. trimera approximately $70 \mathrm{~cm}$ shorter. In contrast, inside the exclosures E. trimera grew faster than $E$. arborea at Duro $(\mathrm{F}=8.85$; $\mathrm{df}=$ $1,266 ; \mathrm{P}=0.003)$, whereas both species grew equally well at Angafu $(\mathrm{F}=3.38$; $\mathrm{df}=1,215 ; \mathrm{P}=$ 0.067) (Fig. 4). At Gama there were too few $E$. arborea individuals inside the browsing exclosure for quantitative comparison. For two year old Erica trimera there was a significant height difference between browsed and fenced individuals, $(\mathrm{F}=$ 215.64; df $=1,139 ; \mathrm{P}=0.004)$ but not for $E$. arborea $(\mathrm{F}=4.46$; df $=1,122 \mathrm{P}=0.282)($ Fig. 4$)$.
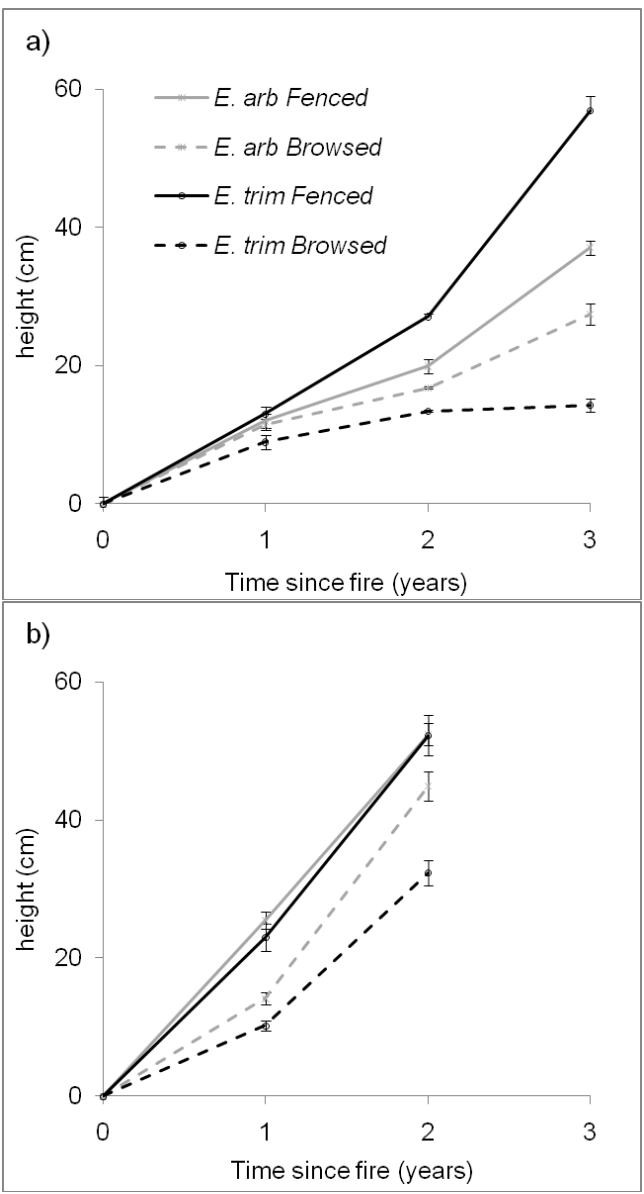

Fig. 4 Height of Erica arborea (grey line) and $E$. trimera (black line) inside (solid line) and outside (dotted line) exclosures set up after fire at a) Duro and b) Angafu. Error bars = S.E. $(n=21-41)$

There were no signs of any browsing on Erica inside the exclosures. In the browsed transects, the average percentage of the bush surface that had been recently browsed was significantly higher in E. trimera $(\mathrm{F}=701.72 ; \mathrm{df}=1,114 ; \mathrm{P}=0.024)$ (Fig. 5).

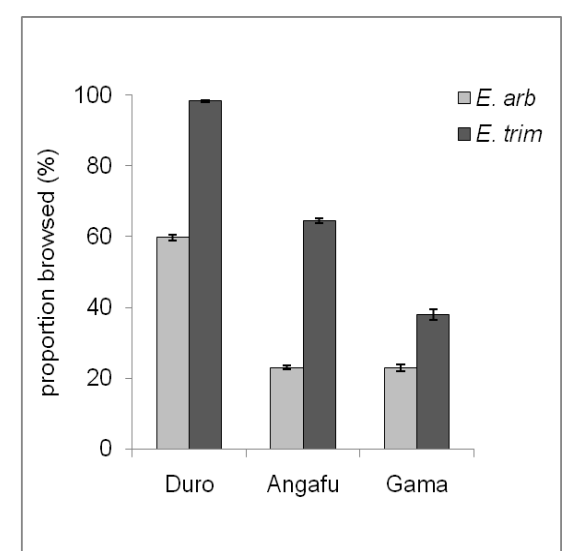

Fig. 5 Average proportion (+/- S.E.) of Erica arborea and E. trimera with recently browsed shoot tips. Measured on 2 (Angafu and Gama) and 3 year (Duro) old individuals in the browsed linetransects in February $2008(n=21-41)$ 
In 2 year old vegetation $3 \%$ of the individuals of Erica arborea had flowering shoots. From the age of 6 years, all E. arborea individuals flowered. There were no flowering shoots on E. trimera before the age of 11 years, and then only on $2 \%$ of the individuals.

There was no difference in the ability of the two species to resprout after the tops of the shoots had been clipped to simulate browsing. The average annual axillary shoot regrowth over 1 year was $12.6 \mathrm{~cm}$ for E. arborea and $11.8 \mathrm{~cm}$ for E. trimera. The maximum height of tree-formed Erica below the tree line was $7.1 \mathrm{~m}$ for E. arborea and $11.2 \mathrm{~m}$ for $E$. trimera. In the greenhouse, seedlings of $E$. trimera grew faster than E. arborea. After 15 months their average heights were $35.8 \mathrm{~cm}$ and $16.1 \mathrm{~cm}$ respectively $(\mathrm{F}=98.11 ; \mathrm{df}=1,50 ; \mathrm{P}<$ $0.001)$.

\section{Chemical analyses}

Shoot dry matter content was significantly higher in E. trimera and increased with age for both species (Fig. 6, Table 2).
Dry matter content was higher in February (at the end of the dry season) than in November. The ADF content was higher in E. trimera and increased slightly with age for both species, but there was no seasonal difference in ADF contents. The protein concentration was higher in E. arborea and decreased with age for both species. There was no significant difference in protein between seasons. Total phenolics content did not differ with species, age or season. Tannin activity was markedly higher in E. trimera but did not differ with age or season (Fig. 6, Table 2).

At Duro, where the fence had been in place for two growth seasons at the time of chemical sampling, the non-fenced individuals of both species had a higher tannin activity $(\mathrm{F}=9.73$; $\mathrm{df}=$ $1,9 ; \mathrm{P}=0.014)$ and higher concentrations of phenolics $(\mathrm{F}=12.00 ; \mathrm{df}=1,9 ; \mathrm{P}=0.009)$ and protein $(\mathrm{F}=7.65 ; \mathrm{df}=1,9 ; \mathrm{P}=0.024)$ than the fenced individuals (Fig. 7). The trend was similar for Angafu and Gama (for E. trimera) but the effect was not statistically significant. There was no significant difference in ADF concentrations between fenced and non-fenced individuals.

Table 2 GLM ANOVA results for shoot chemistry (Fig. 6)

\begin{tabular}{lrrrrrrrrrrr} 
& DF & & DMC & \multicolumn{1}{c}{ ADF } & \multicolumn{1}{c}{ Protein } & Phenolics & \multicolumn{2}{c}{ Tannin } \\
\hline & & $F$ & $P$ & $F$ & $P$ & $F$ & $P$ & $F$ & $P$ & $F$ & $P$ \\
Date & 1 & $\mathbf{1 8 1 . 3 7}$ & $\mathbf{0 . 0 0 5}$ & 0.07 & 0.815 & 4.25 & 0.175 & 5.06 & 0.153 & 1.06 & 0.412 \\
Site & 2 & 0.61 & 0.600 & 0.08 & 0.926 & 0.17 & 0.852 & 8.73 & 0.705 & - & - \\
Age-class & 2 & $\mathbf{1 4 . 7}$ & $\mathbf{0 . 0 1 4}$ & $\mathbf{1 6 . 9 9}$ & $\mathbf{0 . 0 1 1}$ & $\mathbf{1 9 . 7 0}$ & $\mathbf{0 . 0 0 8}$ & 5.62 & 0.069 & 2.64 & 0.186 \\
Species & 1 & $\mathbf{1 4 9 . 0 5}$ & $\mathbf{0 . 0 0 7}$ & $\mathbf{4 7 3 9 . 2 3}$ & $\mathbf{0 . 0 0 0}$ & $\mathbf{2 8 . 1 7}$ & $\mathbf{0 . 0 3 4}$ & 0.01 & 0.934 & $\mathbf{4 8 4 . 6 5}$ & $\mathbf{0 . 0 0 2}$ \\
Date*Site & 2 & 0.20 & 0.817 & 33.87 & 0.063 & 10.12 & 0.150 & 0.91 & 0.623 & 0.36 & 0.758 \\
Date*Age-class & 2 & 1.30 & 0.279 & 9.46 & 0.030 & 1.87 & 0.267 & 0.82 & 0.502 & 0.41 & 0.688 \\
Date*Species & 1 & 0.38 & 0.541 & 12.28 & 0.073 & 10.31 & 0.085 & 0.04 & 0.856 & 3.41 & 0.206 \\
Site*Age-class & 4 & 6.70 & 0.000 & 2.21 & 0.294 & 2.58 & 0.210 & 0.89 & 0.690 & 0.22 & 0.908 \\
Site*Species & 2 & 1.05 & 0.355 & 0.06 & 0.947 & 5.98 & 0.369 & 1.62 & 0.769 & 0.16 & 0.863 \\
Age-class*Species & 2 & 2.34 & 0.103 & 3.17 & 0.150 & 0.38 & 0.704 & 4.66 & 0.090 & 2.24 & 0.223 \\
total & 179 & & & & & & & & & & \\
\hline (-Denominator of F-test is zero) Significant results in bold text There were no significant 3-way interactions & & & & & &
\end{tabular}

$\mathrm{DF}=$ degrees of freedom, $\mathrm{DMC}=$ dry matter content, $\mathrm{ADF}=$ acid detergent fibre

\section{Discussion}

Our results show that the browsers select Erica trimera over E. arborea, and that this leads to a more rapid net height increment in E. arborea in the first years after fire, despite equal or better inherent height growth in E. trimera. Several observations support this conclusion. Erica arborea was significantly taller than E. trimera in browsed vegetation (Fig. 3), whilst E. trimera was taller inside the fences (Fig. 4). Also, E. trimera seedlings grew faster in the controlled greenhouse environment. Further, the higher proportion of the bush surface that had been recently browsed for $E$. trimera (Fig. 5) indicates browser preference for this species. Browsing should mainly be due to cattle, given the low numbers of Mountain Nyala in the area (Stephens et al. 2001).
Since there was only one fence at each site, pseudoreplication may pose a risk. But given our constraints, the need to replicate the study at different sites, with different cattle herds, outweighed the need to replicate the number of fences at each site. Since the vegetation is very uniform, and the results were coherent for all three sites, we believe that our results reflect real patterns in this vegetation.

The reason for the observed preference for Erica trimera is not evident from the chemical screening. Surprisingly, the preferred E. trimera had slightly more ADF, less protein and higher tannin activity than did E. arborea, and these properties would be expected to reduce palatability. However, both species have low protein content and a very high tannin activity, and the differences between them may not be sufficiently large to influence browser selectivity. Their protein 

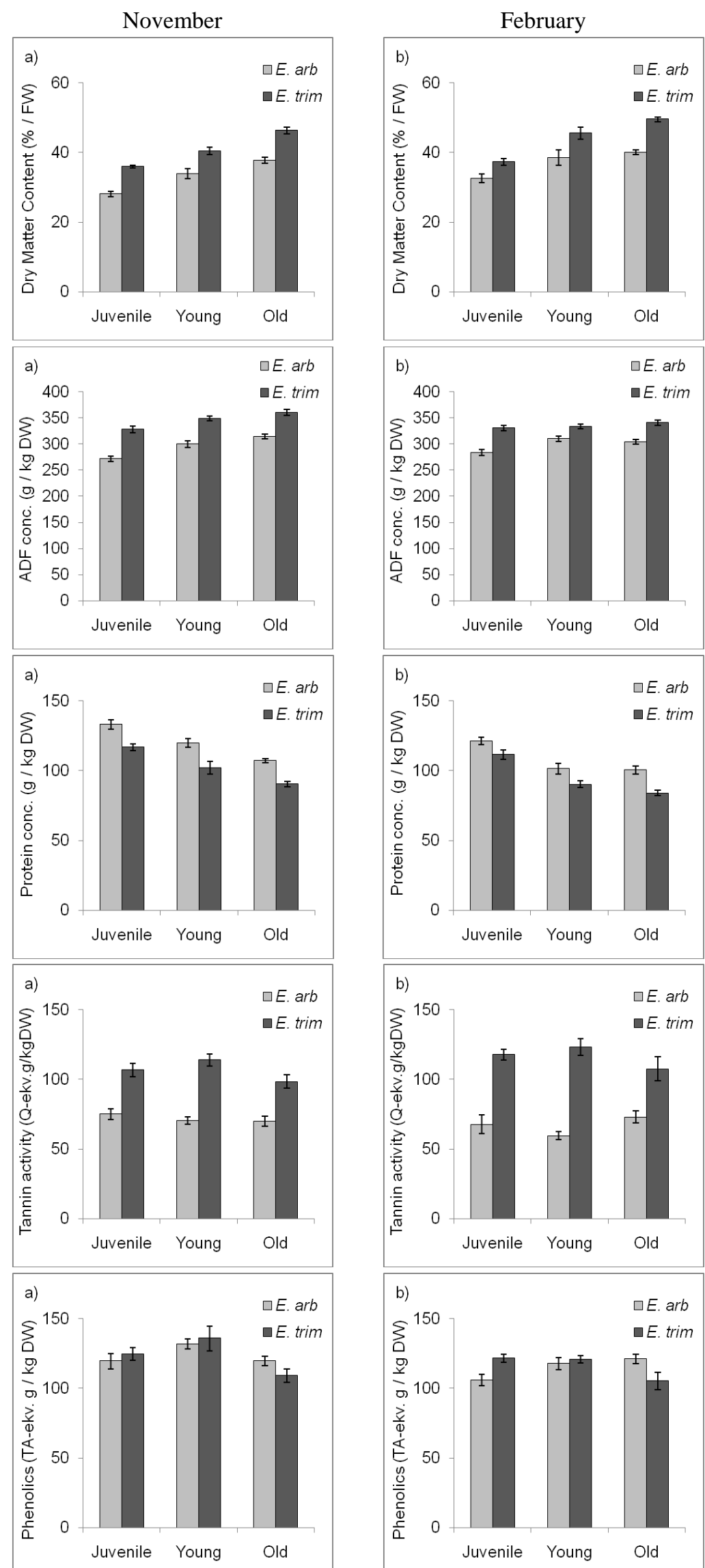

Fig. 6 Average shoot dry matter content, ADF, protein and total phenolics concentrations, and tannin avtivity of Erica arborea and E. trimera in a) November b) February. Error bars $=$ S.E. $(n=15)$ 
concentrations of around $10 \%$ are relatively low for cattle feed (Jackson et al. 1996; Otsyina et al. 1999; Poppi and McLennan 1995) but the concentration is slightly higher in the younger shoots (Fig. 6), indicating that forage value is temporarily increased by burning (Schindler et al. 2004). According to Gustafsson (2009) the cattle spend the major part of their grazing time in recently burnt vegetation. The ADF concentrations of ca. $30 \%$ lie within the range characteristic of temperate and tropical shrubs (Balogun et al. 1998; Blair et al. 1977; Van den Bosch et al. 1997). Meanwhile, tannin activities of 7 and $11 \%$ for $E$. arborea and E. trimera respectively (Fig. 6) are high compared to grasses and herbs, but within the range of other shrubs (Balogun et al. 1998; del Pino et al. 2005; Hanley et al. 1992; Jackson et al. 1996).

Tannins are large polyphenols that act primarily as digestion inhibitors (Robbins et al. 1987). High tannin activity in the forage may be a problem for cattle on a low-protein diet, since cattle are primarily grazers and do not have the tanninbinding proteins in their saliva that specialized browsers have (Austin et al. 1989). Nevertheless, tannins have very different effects on herbivores depending on their chemical structure (Clausen et al. 1990), and there are even some tannins that have a positive effect on cattle nutrition, e.g. by reducing the effects of intestinal parasites (Mueller-Harvey 2006). Further, the BSA-assay may not fully reflect the true effect in the animal. In a livestock nutrition study of different plant species known for their dietary-inhibiting properties, Erica arborea tannins were the most efficient in precipitating BSA, but still had only a minor effect on dietary protein in an in-vitro rumen fermentation experiment (Selje et al. 2007). The fact that we found slightly higher phenolics contents and tannin activity in the browsed compared to fenced individuals for both species (Fig. 7) indicate that phenolics and tannins are partly induced by browsing, but this still does not explain the browser preference for E. trimera.

Although E. trimera had higher tannin activity, levels of total phenolics were comparable between the two species. This suggests that E. arborea contains a higher amount of small, non-tannin phenolic molecules than does E. trimera. Small phenolic compounds can enter through the cell membrane and are therefore potentially more toxic than large-molecule tannins (Ayres et al. 1997). Frequently cited examples are phenolic glycosides, which are efficient mammal herbivore deterrents in Salix (Stolter et al. 2005) and Populus (Donaldson and Lindroth 2007). Phenolic glycosides have been isolated from Mediterranean E. arborea (Nazemiyeh et al. 2008a; Nazemiyeh et al. 2008b) and shoot extracts have been shown to have strong antioxidant and analgesic properties (Mohajjel Nayebi et al. 2008). However, there are many other secondary metabolites functioning as herbivore deterrents, for example terpenes (Lawler et al.
2000; Mueller-Schwarze and Thoss 2008; Vourc'h et al. 2001). High terpene emissions have been reported from Mediterranean populations of $E$. arborea (Llusia and Penuelas 2000; Peñuelas et al. 2002), but nothing is known of E. trimera in this respect. Given the similar shoot architecture and similar nutrition value for the two species, the key to the differing browsing preference is likely to be some chemical deterrence, which prompts further comparative studies of their secondary chemistry.

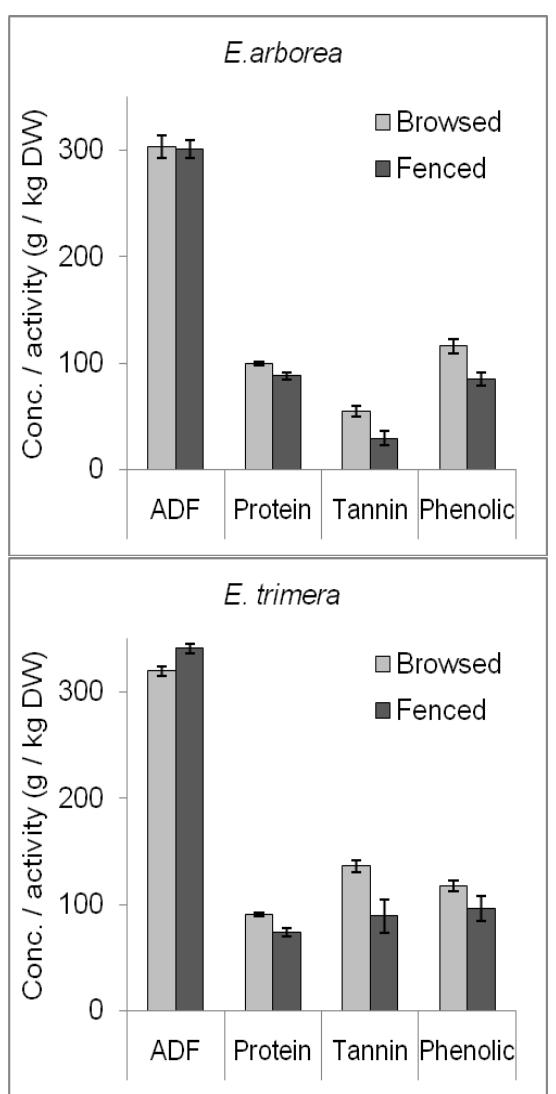

Fig. 7 Average concentrations of ADF, protein and total phenolics and tannin avtivity of Erica arborea and $E$. trimera inside and outside browsing exclosures at Duro. Error bars $=$ S.E. $(n=5)$

The present disturbance regime of fire and browsing favours $E$. arborea, but both factors need to act in consort. The heavy browsing pressure allows E. arborea to outgrow E. trimera in early succession after fire. Nevertheless, there is still a yearly height increment of both species, and without short-interval fire E. trimera would instead finally out-shade $E$. arborea, since its height at maturity is taller. This form of competitive exclusion is the likely reason for E. arborea to be nearly absent from the present Erica forest stands of the area (Miehe and Miehe 1994). Judging from ring counts on felled $8-11 \mathrm{~m}$ tall tree stems (diameter $15-30 \mathrm{~cm}$ ), we believe that such tree stands have not burned for at least 90 years (M. Johansson, personal observation).

It is clear that $E$. arborea achieves a higher net growth rate under heavy browsing pressure, but the question remains as to whether this actually 
translates into a long-term competitive advantage, given that the repeated fire kill all above-ground structures. Fire then acts as an alternative consumer of plant biomass (Bond and Keeley 2005), but it is non-selective in contrast to the animal herbivores. Thus, each fire would tend to even out the score of the previous period of competition, although there are also potential carry-over effects: The smaller foliage loss to browsers in E. arborea could allow for the accumulation of larger stores of carbohydrates and nutrients in the lignotuber (Canadell and Lopez-Soria 1998; Paula and Ojeda 2006), which could in turn result in better post-fire growth and progressively increase the differences between the species over each cycle of fire and regrowth. Another potential legacy of the pre-burn status is the dead Erica stems. When the fire-killed stems are numerous and large, they could provide some protection from browsing in the first couple of years (Davis 1967). The most important mechanism in the long run, however, should be the more effective sexual regeneration in E. arborea. Profuse flowering was found only for E. arborea within the typical 6-10 year fire cycle, and this is consistent with the occurrence of occasional seedlings of $E$. arborea but not of E. trimera at these sites (M. Johansson unpublished). We do not know if the higher browsing pressure on E. trimera has an influence on flowering frequency, because the exclosures were not old enough, but it is not unlikely that browsing as well as short-interval fire would enhance any inherent differences in fruiting patterns.

In conclusion, we would suspect that there is a slow, gradual increase in the proportion of $E$. arborea that may have been acting over a very long time. Judging by the huge sizes of the Erica trimera lignotubers (frequently more than $1 \mathrm{~m}$ in diameter) fire has been prevalent in these heathlands over centuries, although browsing pressure has most likely increased substantially over the last decades due to dramatically increasing human populations (Stephens et al. 2001). Nevertheless, certain traits in this system would provide for considerable resistance to change, despite large differences between species in net growth. First, repeated fires will set the system back before serious interspecific competition ensues. Second, the presence of large, resprouting lignotubers should result in low population turnover.

\section{Acknowledgements}

We thank Ayano Abraham and Shebru Marefu for field assistance, Helena Königsson for lab assistance, Sören Holm for statistics support and Christina Skarpe and David Wardle for valuable comments on the manuscript. The study was funded by The Swedish International Development Cooperation Agency.

\section{References}

anonymous (2000) Leco Application Note

"Nitrogen/Protein in animal feeds". In:

Form 203-821-146

http://www.leco.com/resources/applicatio $\mathrm{n}$ note subs/pdf/organic/-146.pdf

anonymous (2005) Acid Detergent Fiber in feeds filter bag technique ANKOM200 In: http://www.ankom.com/09 procedures/A DF 81606 A200.pdf

Augustine DJ, McNaughton SJ (1998) Ungulate effects on the functional species composition of plant communities: Herbivore selectivity and plant tolerance. J Wildlife Manage 62:1165-1183

Austin PJ, Suchar LA, Robbins CT, Hagerman AE (1989) Tannin-binding proteins in saliva of deer and their absence in saliva of sheep and cattle. J Chem Ecol 15:13351347

Ayres MP, Clausen TP, MacLean SF, Redman AM, Reichardt PB (1997) Diversity of structure and antiherbivore activity in condensed tannins. Ecology 78:1696-1712

Balogun RO, Jones RJ, Holmes JHG (1998) Digestibility of some tropical browse species varying in tannin content. Anim Feed Sci Tech 76:77-88

Bartolome J, Franch J, Plaixats J, Seligman NG (1998) Diet selection by sheep and goats on Mediterranean heath-woodland range. J Range Manage 51:383-391

Blair RM, Short HL, Epps EA, Jr. (1977) Seasonal nutrient yield and digestibility of deer forage from a young pine plantation. $\mathrm{J}$ Wildlife Manage 41:667-676

Bond WJ, Keeley JE (2005) Fire as a global 'herbivore': the ecology and evolution of flammable ecosystems. Trends Ecol Evol 20:387-394

Canadell J, Lopez-Soria L (1998) Lignotuber reserves support regrowth following clipping of two Mediterranean shrubs. Funct Ecol 12:31-38

Clausen TP, Provenza FD, Burritt EA, Reichardt PB, Bryant JP (1990) Ecological implications of condensed tannin structure - a case study. J Chem Ecol 16:2381-2392

Davis J (1967) Some effects of deer browsing on chamise sprouts after fire. Am Midl Nat 77:234-238

del Pino MCA, Hervas G, Mantecon AR, Giraldez FJ, Frutos P (2005) Comparison of biological and chemical methods, and internal and external standards, for assaying tannins in Spanish shrub species. J Sci Food Agr 85:583-590

Donaldson JR, Lindroth RL (2007) Genetics, environment, and their interaction determine efficacy of chemical defense in trembling aspen. Ecology 88:729-739 
Dwire KA, Ryan SE, Shirley LJ, Lytjen D, Otting N, Dixon MK (2006) Influence of herbivory on regrowth of riparian shrubs following a wildland fire. In. Amer Water Resources Assoc, pp 201-212

FAO (1998) World reference base for soil resources. In. FAO, Rome

Fetene M, Assefa, Y., Gashaw, M., Woldu, Z., Beck, E (2008) Diversity of Afroalpine Vegetation and Ecology of Treeline Species in the Bale Mountains, Ethiopia, and the Influence of Fire. In: Spehn E, Liberman M, Korner C (eds) Land Use Change and Mountain Biodiversity

Focardi S, Tinelli A (2005) Herbivory in a Mediterranean forest: browsing impact and plant compensation. Acta Oecol 28:239-247

Frutos P, Hervas G, Ramos G, Giraldez FJ, Mantecon AR (2002) Condensed tannin content of several shrub species from a mountain area in northern Spain, and its relationship to various indicators of nutritive value. Anim Feed Sci Tech 95:215-226

Gasmi-Boubaker A, Kayouli C, Buldgen A (2006) Feed blocks as a supplement for goat kids grazing natural Tunisian rangeland during the dry season. Anim Feed Sci Tech 126:31-41

González Hernandez MP (2004) Quality of vegetation in silvopastoral systems. In: Mosquera-Losada MR, Rigueiro Rodríguez A, McAdam J (eds) Proceedings of an International Congress on Silvopastoralism and Sustainable Management. CABI Publishing, Lugo, Spain, pp 87-92

Gonzalez Hernandez MP, Silva-Pando FJ (1996) Grazing effects of ungulates in a Galician oak forest (northwest Spain). For Ecol Manage:65-70

Grime JP, Cornelissen JHC, Thompson K, Hodgson JG (1996) Evidence of a causal connection between anti-herbivore defence and the decomposition rate of leaves. Oikos 77:489-494

Gustafsson J (2009) Habitat and plant selection of livestock in a fire-managed Afro-alpine heathland in Ethiopia. MSc thesis. Department for Forest Ecology and Management, Swedish University of agricultural Sciences

Hagerman AE (1987) Radial diffusion method for determining tannin in plant extracts. $\mathbf{J}$ Chem Ecol 13:437-449

Hanley TA, Robbins CT, Hagerman AE, McArthur C (1992) Predicting digestible protein and digestible dry matter in tannin-containing forages consumed by ruminants. Ecology 73:537-541
Harborne JB, Williams CA (1973) A

chemotaxonomic survey of flavonoids and simple phenols in leaves of the Ericaceae. Bot J Linn Soc 66:37-54

Harbourne JG (1991) The chemical basis of plant defence. In: Robbins CT (ed) Plant Defences Against Mammalian Herbivory. CRC Press Inc., London, pp 45-59

Hedberg O (1951) Vegetation belts of the East African mountains. Sven Bot Tidskr 45:140-201

Hedberg O (1971) The high mountain flora of the Galama Mountain in Arussi Province, Ethiopia. Webbia 26:101-128

Herms DA, Mattson WJ (1992) The dilemma of plants - To grow or to defend. Q Rev Biol 67:478-478

Hobbs NT (1996) Modification of ecosystems by ungulates. J Wildlife Manage 60:695-713

Horsley SB, Stout SL, DeCalesta DS (2003) Whitetailed deer impact on the vegetation dynamics of a northern hardwood forest. Ecol Appl 13:98-118

Jackson FS, McNabb WC, Barry TN, Foo YL, Peters JS (1996) The condensed tannin content of a range of subtropical and temperate forages and the reactivity of condensed tannin with ribulose-1,5-bisphosphate carboxylase (Rubisco) protein. J Sci Food Agr 72:483-492

Jones DB (1941) Factors for converting percentages of nitrogen in foods and feeds into percentages of protein. In: Agriculture USDo (ed), vol. Circ. No. 183, Washington DC

Koricheva J (2002) Meta-analysis of sources of variation in fitness costs of plant antiherbivore defenses. Ecology 83:176190

Lawler IR, Foley WJ, Eschler BM (2000) Foliar concentration of a single toxin creates habitat patchiness for a marsupial folivore. Ecology 81:1327-1338

Llusia J, Penuelas J (2000) Seasonal patterns of terpene content and emission from seven Mediterranean woody species in field conditions. Am J Bot 87:133-140

Miehe G, Miehe S (1994) Ericaceous forests and heathlands in the Bale Mountains of South Ethiopia : Ecology and man's impact. Stiftung Walderhaltung in Africa, Hamburg

Mills JN (1986) Herbivores and early postfire succession in southern California Chaparral. Ecology 67:1637-1649

Mohajjel Nayebi A, Nazemiyeh H, Omidbakhsh R, Çobanoglu S (2008) Analgesic effect of the methanol extract of Erica arborea (L.) in mice using formalin test. Daru 16:229232

Mueller-Harvey I (2006) Unravelling the conundrum of tannins in animal nutrition 
and health. In. John Wiley \& Sons Ltd, pp 2010-2037

Mueller-Schwarze D, Thoss V (2008) Defense on the rocks: Low Monoterpenoid levels in plants on pillars without mammalian herbivores. J Chem Ecol 34:1377-1381

Nazemiyeh H et al. (2008a) Tricetin 4 '-O-alpha-Lrhamnopyranoside: A new flavonoid from the aerial parts of Erica arborea. Chem Nat Compd 44:174-177

Nazemiyeh H et al. (2008b) Antioxidant phenolic compounds from the leaves of Erica arborea (Ericaceae). Nat Prod Res 22:1385-1392

Ormeno E et al. (2009) The relationship between terpenes and flammability of leaf litter. For Ecol Manage 257:471-482

Otsyina RM, B.W. N, M. D (1999) Fodder trees and shrubs in arid and semi-arid livestock production systems. In: In 'XVIII International Grassland Congress, vol. 2, pp 429-438

Owens MK, Lin CD, Taylor CA, Whisenant SG (1998) Seasonal patterns of plant flammability and monoterpenoid content in Juniperus ashei. J Chem Ecol 24:21152129

Paula S, Ojeda F (2006) Resistance of three cooccurring resprouter Erica species to highly frequent disturbance. Plant Ecol 183:329-336

Peñuelas J, Castells E, Joffre R, Tognetti R (2002) Carbon-based secondary and structural compounds in Mediterranean shrubs growing near a natural $\mathrm{CO} 2$ spring. Glob Change Biol 8:281-288

Pereira JMC, Sequeira NMS, Carreiras JMB (1995) Structural-properties and dimensional relations of some Mediterranean shrub fuels. Int J Wildland Fire 5:35-42

Poppi DP, McLennan SR (1995) Protein and energy-utilization by ruminants at pasture. J Anim Sci 73:278-290

Robbins CT, Mole S, Hagerman AE, Hanley TA (1987) Role of tannins in defending plants against ruminants: reduction in protein availability. Ecology 68:1606-1615

Schindler JR, Fulbright TE, Forbes TDA (2004) Shrub regrowth, antiherbivore defenses, and nutritional value following fire. $\mathbf{J}$ Range Manage 57:178-186

Selje N, Hoffmann EM, Muetzell S, Ningrat R, Wallace RJ, Becker K (2007) Results of a screening programme to identify plants or plant extracts that inhibit ruminal protein degradation. Br J Nutr 98:45-53

Skarpe C, Hester AJ (2008) Plant traits, browsing and gazing herbivores, and vegetation dynamics. In: Gordon IJ, Prins HHT (eds)
The Ecology of Browsing and Grazing. Ecological Studies Vol. 195, pp 217-261

Snyder JR (1984) The role of fire - Much ado about nothing. Oikos 43:404-405

Stephens PA, d'Sa CA, Sillero-Zubiri C, LeaderWilliams N (2001) Impact of livestock and settlement on the large mammalian wildlife of Bale Mountains National Park, southern Ethiopia. Biol Conserv 100:307322

Stolter C, Ball JP, Julkunen-Tiitto R, Lieberei R, Ganzhorn JU (2005) Winter browsing of moose on two different willow species: food selection in relation to plant chemistry and plant response. Can J Zool 83:807-819

Teshome T (1999) Effects of grazing and fire on tree regeneration in coniferous montane forest of the Dodola area, Ethiopia. In: Faculty of forestry and ecology, vol. MSc. Georg-August University, Göttingen, p 59

Van den Bosch S, Guevara JC, Tacchini FM, Estevez OR (1997) Nutrient content of browse species in the arid rangelands of the Mendoza plain, Argentina. J Arid Environ 37:285-298

Wardle DA, Bonner KI, Barker GM (2002) Linkages between plant litter decomposition, litter quality, and vegetation responses to herbivores. Funct Ecol 16:585-595

Waterman PG, Mole S (1994) Analysis of phenolic plant metabolites. Blackwell Scientific Publications, Oxford

Weinert E, Mazurek A (1984) Notes on vegetation and soil in Bale Province of Ethiopia. Feddes Repertorium 95:373-380

Wesche K, Cierjacks A, Assefa Y, Wagner S, Fetene M, Hensen I (2008) Recruitment of trees at tropical alpine treelines: Erica in Africa versus Polylepis in South America. Plant Ecol Divers 1:35 - 46

Wesche K, Miehe G, Kaeppeli M (2000) The significance of fire for afroalpine ericaceous vegetation. Mt Res Dev:340347

Vourc'h G, Martin JL, Duncan P, Escarre J, Clausen TP (2001) Defensive adaptations of Thuja plicata to ungulate browsing: a comparative study between mainland and island populations. Oecologia 126:84-93

Yimer F, Ledin S, Abdelkadir A (2006) Soil property variations in relation to topographic aspect and vegetation. community in the south-eastern highlands of Ethiopia. For Ecol Manage 232:90-99 